\title{
Determinan Pemilihan Tempat Persalinan di Kabupaten Cirebon, Tahun 2004
}

\author{
Deti Adipriati*
}

\begin{abstract}
Abstrak
Lebih dari 90 \% kematian ibu disebabkan komplikasi obstetrik yang sering tidak dapat diramalkan pada saat kehamilan. Pada umumnya kematian lbu dan kejadian kesakitan setelah bayi lahir adalah akibat kegagalan untuk menanggulangi komplikasi persalinan. Kebanyakan komplikasi itu terjadi pada saat atau sekitar persalinan. SDKI 2003 melaporkan bahwa $9 \%$ persalinan dilakukan di fasilitas pemerintah dan $31 \%$ pada fasilitas swasta, sedangkan $59 \%$ masih dilakukan di rumah. Pertolongan persalinan di rumah, dimana sistem rujukan tidak dikembangkan dengan tepat, memiliki pengaruh yang besar terhadap kelangsungan hidup ibu dan bayi. Penelitian ini bertujuan untuk mengetahui faktor-faktor yang berpengaruh dalam menentukan pemilihan tempat persalinan di Kabupaten Cirebon tahun 2004. Desain penelitian menggunakan desain potong lintang (cross sectional) pada 447 responden pada 29 desa di kabupaten Cirebon. Analisa yang digunakan adalah regresi logistik model prediksi. Hasil penelitian didapatkan bahwa ibu berpendidikan rendah akan memilih tempat persalinan di rumah sebanyak 2.94 kali dibandingkan ibu berpendidikan tinggi ( $\mathrm{OR}=2,9495 \% \mathrm{Cl} 1.764-4.890)$ setelah dikontrol oleh variable pengetahuan ibu tentang masalah kesehatan pada masa persalinan dan melahirkan dan variable status ekonomi. Penelitian menyimpulkan bahwa pendidikan Ibu, pengetahuan ibu tentang masalah kesehatan pada masa kehamilan dan persalinan serta status ekonomi mempunyai pengaruh terhadap pemilihan tempat persalinan
\end{abstract}

Kata kunci : Pemilihan tempat persalinan, pengetahuan ibu, status ekonomi

\begin{abstract}
More than $90 \%$ of maternal death is caused by obstetric complications, which are often unpredictable during pregnancy. In general, maternal death and newborn morbidity are caused by failure to overcome delivery complication. Most of the complication happened at the moment or around delivery. SDKI 2003 reported that $9 \%$ birth were delivered in public facilities, $31 \%$ were delivered in private health facilities and $59 \%$ were still delivered at home. Birth delivery at home with not well-developed referral system, has great influence on mother and newborn lives. The objective of this study is to identify factors that influence selection of delivery place in Cirebon district in 2004 using cross-sectional design among 447 respondents living in 29 villages in Cirebon District. The analysis used is logistic regression using prediction modeling. The results indicate that mother with low education has chance to opt for delivery at home 2.94 times higher than mother with high education level $(\mathrm{OR}=2.9495 \% \mathrm{Cl} 1.764-4.890)$ after controlled by mother's knowledge on health problem at birth and economic status. The study concludes that delivery place selection is influenced by mother's education, mother's knowledge on health problem at birth and economic status.
\end{abstract}

Key words : Delivery place selection, mother's knowledge on health problem, economic status

*Kepala UPTD Puskesmas Jambe, Tangerang 
Di negara berkembang, mortalitas dan mordibitas wanita hamil dan bersalin masih merupakan masalah kesehatan masyarakat yang penting dan serius. Pada tahun 1996, WHO memperkirakan, setiap tahunnya lebih dari $585.000 \mathrm{ibu}$ meninggal pada saat hamil atau bersalin Kaum ibu di Asia Selatan berisiko 1/18 untuk meninggal akibat kehamilan dan persalinan, sedangkan di banyak negara Afrika risiko tersebut adalah 1/14. Risiko kematian ibu tersebut jauh lebih besar dari negaranegara di Amerika Utara yang besarnya $1 / 6.366 .{ }^{1}$

Lebih dari 90\% kematian ibu tersebut disebabkan oleh komplikasi obstetrik yang sering tidak dapat diramalkan pada masa kehamilan dan awal masa persalinan. Umumnya, komplikasi tersebut terjadi pada saat atau sekitar masa persalinan. Diperkirakan 15 persen kehamilan akan mengalami keadaan risiko tinggi dan komplikasi obstetrik dan jika tidak ditangani secara memadai dapat membahayakan kehidupan ibu dan janin yang dikandung. ${ }^{2}$ Oleh sebab itu, pendekatan yang dianjurkan adalah mengganggap semua kehamilan tersebut berisiko dan setiap ibu hamil mempunyai akses pada pertolongan persalinan yang aman.

Pada tahun 1992, 1995 dan 2003, Angka Kematian Ibu di Indonesia memperlihatkan kecenderungan menurun secara perlahan, yaitu 425,373 dan 307 per 100.000 kelahiran hidup. Target kematian ibu yang ingin dicapai secara nasional pada tahun 2010 adalah sebesar 125 per 100.000 kelahiran hidup. ${ }^{3}$ Berdasarkan data tahun 2001, 2002 dan 2003, Angka Kematian Bayi juga mengalami penuruhan perlahan yaitu 50,47 dan 37 per 1.000 kelahiran hidup pada tahun 2003. ${ }^{4}$ Meskipun demikian, penurunan tersebut jauh tertinggal jika dibandingkan dengan negara-negara ASEAN. Sebagai perbandingan, di negara tetangga Angka Kematian Bayi tersebut berada pada kisaran 20 - 30 per 1.000 kelahiran hidup. Di Indonesia, Risiko kematian ibu akibat melahirkan (1 dari 65), jauh lebih besar daripada di risko kematian ibu di Thailan (1 dari 1.100). ${ }^{5}$

Berdasarkan data SDKI 2003, diketahui bahwa proporsi ibu yang bersalinan di rumah $(59 \%)$ jauh lebih tinggi daripada proporsi ibu yang bersalinandi fasilitas pelayanan kesehatan pemerintah dan swasta $(30.5 \%$ dan $9.2 \%$ ). Selain itu, ibu di daerah pedesaan, pada ibu berpeluang dua kali lebih besar untuk bersalin di rumah dari pada ibu di daerah perkotaan (76\% dan 40\%). Keadaan ini diduga merupakan faktor penting yang berpengaruh terhadap kejadian komplikasi persalinan.

Penyebab langsung kematian ibu di Indonesia adalah perdarahan (40-60\%), infeksi (20 -30\%) dan eklampsi (20-30\%). Penyebab tidak langsung kematian ibu antara lain akibat anemia, kurang energi khronis dan keadaan "4 Terlalu" (terlalu muda/tua, terlalu sering, terlalu banyak), selain itu hal non teknis yang masuk katagori penyebab mendasar yaitu rendahnya status wanita, ke- tidak berdayaan dalam mengambil keputusan dan pendidikan yang rendah. ${ }^{6}$ Survei yang diselenggarakan hasil kerjasama antara BKKBN dengan BPS dan Depkes, menjelaskan bahwa lebih dari 40 persen ibu tidak mengetahui komplikasi persalinan dan lebih dari 50 persen ibu-ibu tidak mengetahui komplikasi masa nifas. ${ }^{7}$

Menurut Pratomo, 8 faktor penting yang berpengaruh terhadap kejadian kematian bayi neonatal (0-28 hari) di Indonesia adalah persalinan yang dilakukan dirumah. Sebagian besar kematian neonatal terjadi pada persalinan di rumah $(54,2 \%)$. Kematian neonatal sebagian besar terjadi di wilayah Jawa Bali $(66,7 \%)$ dan di daerah pedesaan $58,6 \%$. Berdasarkan umur kematian, sekitar 79,4\% kematian neonatal terjadi sampai usia 7 hari, dan 20,6\% terjadi pada usia $8-28$ hari. Penyebab kematian neonatal tertinggi adalah berat lahir rendah $(35 \%)$, kemudian asfiksia lahir $(33,6 \%)$. Di daerah kabupaten, persalinan di rumah sebagian besar ditolong oleh tenaga kesehatan. Budaya pertolongan persalinan di rumah, yang tidak mengembangkan sistem rujukan secara tepat, berpengaruh besar terhadap kelangsungan hidup ibu dan bayi.

Penelitian ini bertujuan untuk mengetahui berbagai faktor yang berpengaruh terhadap pemilihan tempat persalinan.

\section{Metode}

Penelitian ini menggunakan sumber data sekunder Baseline Survey Saving Newborn Lives (Survey Data Dasar Upaya Kelangsungan Hidup Bayi Baru lahir) Kabupaten Cirebon Tahun 2004, dengan menggunakan rancangan studi epidemiologi potong lintang (cross sectional). Penelitian dilakukan di Kabupaten Cirebon, Jawa Barat, mencakup 29 desa yang tersebar pada 17 Kecamatan di Kabupaten Cirebon. Populasi studi adalah pemilik rumah yang tinggal permanen atau cenderung tinggal permanen di tempat tinggal mereka. Populasi target adalah ibu yang memiliki bayi berumur di bawah 1 tahun. Pengumpulan data dilakukan dengan metode wawancara tatap muka di rumah responden dengan menggunakan instrumen kuesioner terstuktur yang dikembangkan oleh PATH dan Departemen Kesehatan. Jumlah subjek yang diteliti pada penelitian ini adalah 450 responden yang ditarik secara purposif. Setelah dilakukan recoding dan cleaning, data yang dianalisis adalah 447 responden. Variabel yang dikumpulkan meliputi, umur ibu, pendidikan ibu, paritas, pengetahuan tentang kesehatan persalinan, kesehatan setelah melahirkan, kesehatan bayi $0-7$ hari, persepsi jarak, persepsi biaya transportasi dan status ekonomi Untuk variable status ekonomi dilakukan komposit kepemilikan barang tahan lama dan kepemilikan rumah, sehingga didapatkan 5 katagori status ekonomi. 
Tabel 1. Distribusi Responden berdasarkan Tempat Persalinan

\begin{tabular}{|c|c|c|c|c|c|}
\hline \multirow[t]{3}{*}{ Variabel } & \multirow[t]{3}{*}{ Katagori } & \multicolumn{4}{|c|}{ Tempat Persalinan } \\
\hline & & \multicolumn{2}{|c|}{ Rumah } & \multicolumn{2}{|c|}{ Yankes } \\
\hline & & $\mathbf{n}$ & $\%$ & $\mathbf{n}$ & $\%$ \\
\hline \multirow[t]{3}{*}{ Umur Ibu } & $<=19$ th & 13 & 4.7 & 8 & 4.7 \\
\hline & $20-34$ th & 219 & 79.6 & 133 & 77.3 \\
\hline & $>=35$ th & 43 & 15.7 & 91 & 18.0 \\
\hline \multirow[t]{2}{*}{ Pendidikan Ibu } & Rendah & 242 & 88.0 & 123 & 41.5 \\
\hline & Tinggi & 33 & 12.0 & 49 & 28.5 \\
\hline \multirow[t]{2}{*}{ Paritas } & 1 dan $>4$ & 154 & 56.0 & 69 & 40.1 \\
\hline & $2-3$ & 121 & 44.0 & 103 & 59.9 \\
\hline \multirow[t]{2}{*}{ Pengetahuan kesehatan persalinan } & Tahu & 7 & 2.5 & 8 & 4.6 \\
\hline & Tidak Tahu & 268 & 97.5 & 164 & 95.4 \\
\hline \multirow[t]{2}{*}{ Kesehatan setelah Melahirkan } & Tahu & 26 & 9.4 & 15 & 8.7 \\
\hline & Tidak Tahu & 249 & 90.6 & 157 & 91.3 \\
\hline \multirow[t]{2}{*}{ Kesehatan bayi $0-7$ hari } & Tahu & 7 & 2.6 & 7 & 4.1 \\
\hline & Tidak Tahu & 268 & 97.4 & 165 & 95.9 \\
\hline
\end{tabular}

Tabel 2. Hubungan Faktor Predisposing dengan Pemilihan Tempat Persalinan

\begin{tabular}{lllll}
\hline Variabel & Katagori & $\mathbf{p}$ & OR & 95 \% CI \\
\hline Umur Ibu & $20-34$ th & 0.975 & 1.01 & $0.44-2.37$ \\
& $\geq 35$ th & 0.693 & 0.85 & $0.38-1.92$ \\
Pendidikan Ibu & Tinggi & 0.000 & 2.92 & $1.74-4.928$ \\
Paritas & 1 atau >4 & 0.594 & 0.85 & $0.46-1.56$ \\
Pengetahuan kehamilan \& persalinan & Tidak Tahu & 0.185 & 1.87 & $0.73-4.79$ \\
Pengetahuan kesehatan setelah melahirkan & Tidak Tahu & 0.185 & 0.92 & $0.42-1.98$ \\
Pengetahuan kesehatan bayi neonatal & Tidak Tahu & 0.319 & 1.62 & $0.61-0.43$ \\
& & & & \\
\hline
\end{tabular}

\section{Hasil}

Proporsi ibu yang melahirkan dirumah sebesar $61,5 \%$. Distribusi umur ibu pada kelompok yang lahir di rumah dan yankes tak terlihat berbeda. Berdasarkan pendidikan, ibu yang melahirkan di rumah sebagian besar berpendidikan rendah. Berdasarkan paritas ibu yang melahirkan di rumah lebih banyak dengan paritas 1 dan $>4$. Berdasarkan pengetahuan, tak ada perbedaan antara ibu yang lahir dirumah dan lahir di yankes (Lihat tabel 1).

Pada analisis bivariat, dari 9 variabel independen yang dianalisis, hanya variabel pendidikan yang berhubungan secara bermakna dengan pemilihan tempat persalinan. Variabel yang masuk sebagai kandidat model multivariat adalah variabel pendidikan, pengetahuan ibu tentang kesehatan kehamilan dan persalinan serta variabel status ekonomi.

Dari hasil analisis multivariat didapatkan model yang menyatakan bahwa, ibu yang berpendidikan rendah akan memilih tempat persalinan di rumah sebanyak 2.94 kali debandingkan dengan ibu berpendidikan tinggi $(\mathrm{OR}=2.9495 \%$ CI $1.76-4.89)$ setelah dikontrol oleh variabel pengetahuan ibu tentang masalah kesehatan pada masa kehamilan dan persalinan serta variabel status ekonomi.

\section{Model akhir}

Variabel yang masuk model akhir adalah pendidikan ibu, pengetahuan ibu dan status sosial ekonomi yang terdiri dari 6 katagori dengan tingkat terendah sebagai referensi. (Lihat Tabel 4)

\section{Pembahasan}

Pada penelitian ini, responden yang memilih bersalin di rumah sebesar $275(61.5 \%)$. Hasil ini tidak jauh berbeda dengan data SDKI 2002-2003 yang melaporkan bahwa yang memilih tempat persalinan di rumah adalah sebesar $59 \%$. Menurut Monthe, ${ }^{9}$ alasan ibu bersalinan di rumah antara lain adalah dekat dengan rumah bidan; dekat dengan ibu (orang tua); dekat dengan suami, ada orang tua yang membantu dan merawat, menghemat biaya, lebih leluasa dibandingkan bila di rumah sakit. Selain itu, jika selama kehamilan ibu tidak mengalami gangguan, maka ibu memilih melahirkan di rumah.

Penelitian ini menemukan bahwa variabel umur, paritas, pengetahuan ibu tentang kehamilan dan persalinan, pengetahuan ibu tentang kesehatan setelah persalinan, pengetahuan ibu tentang kesehatan bayi 0-7 hari, persepsi ibu tentang jarak dari rumahnya ke tenaga kesehatan yang terdekat, persepsi ibu tentang biaya transportasi ke tempat tenaga terlatih yang terdekat, 
Tabel 3. Hubungan Faktor Pendukung dan Tempat Persalinan

\begin{tabular}{lllll}
\hline Faktor Pendukung & Katagori & p & OR & 95 \% CI \\
\hline Persepsi jarak & Dekat & 0.639 & 0.87 & $0.49-1.54$ \\
Persepsi biaya transportasi & Murah & 0.786 & 0.91 & $0.48-1.74$ \\
Status Ekonomi & Terbawah & 0.061 & 1.66 & $0.98-2.82$ \\
& Menengah Bawah & 0.315 & 1.32 & $0.76-2.28$ \\
& Menengah & 0.519 & 1.36 & $0.52-3.58$ \\
& Menengah Atas & 0.447 & 0.92 & $0.45-1.89$ \\
\hline
\end{tabular}

Tabel 4. Model Akhir Faktor Penentu Pemilihan Tempat Persalinan

\begin{tabular}{lccccc}
\hline Variabel & $\boldsymbol{\beta}$ & $\mathbf{S E}$ & $\mathbf{p}$ & OR & $\mathbf{9 5} \% \mathbf{C I}$ \\
\hline Pendidikan Ibu & 1.08 & 0.73 & 0.00 & 2.94 & $1.76-4.89$ \\
Pengetahuan Ibu & 0.66 & 1.05 & 0.23 & 1.94 & $0.64-5.87$ \\
Stsek 2 & 0.63 & 0.52 & 0.03 & 1.87 & $1.08-3.26$ \\
Stsek 3 & 0.32 & 0.38 & 0.26 & 1.37 & $0.78-2.41$ \\
Stsek 4 & 0.36 & 0.67 & 0.45 & 1.43 & $0.55-3.72$ \\
Stsek 5 & 0.24 & 0.44 & 0.51 & 1.26 & $0.55-3.71$ \\
Const & 1.35 & 0.62 & 0.04 & & $-2.61--0.88$ \\
\hline
\end{tabular}

tidak berhubungan bermakna dengan pemilihan tempat persalinan di rumah. Keadaan ini dapat terjadi karena beberapa hal antara lain faktor sosial budaya, perilaku, sikap, kurangnya informasi (melalui penyuluhan, informasi dari media), pengalaman sendiri atau pengalaman orang lain, kepercayaan, tradisi, nilai dan pengaruh kelompok referensi dalam menentukan pilihan tempat persalinan sosial. ${ }^{10}$

Walaupun dari analisis hubungan bivariat, variabel pengetahuan ibu tentang masalah kesehatan pada masa kehamilan dan persalinan dan variabel status ekonomi tidak memperlihatkan hubungan yang signifikan, tetapi pada analisis multivariat, variabel-variabel ini memiliki kontribusi sebagai konfounder. Hal ini cukup menjelaskan bahwa terdapat pengaruh pengetahuan ibu dan status ekonomi dalam menentukan pemilihan tempat persalinan di rumah.

\section{Kesimpulan}

1. Proporsi terbesar melahirkan di rumah adalah kelompok ibu yang tidak tahu tentang masalah kesehatan pada bayi $0-7$ hari

2. Tidak ada perbedaan bermakna secara statistik antara umur ibu, paritas, pengetahuan ibu tentang kesehatan masa kehamilan dan persalinan; masalah kesehatan setelah persalinan, masalah kesehatan bayi 0 - 7 hari, persepsi jarak rumah - nakes terlatih terdekat, persepsi biaya transportasi rumah- nakes terdekat terhadap pemilihan tempat persalinan.

3. Pada model akhir analisis multivariat ditemukan ibu berpendidikan rendah berisiko 3 kali lebih besar untuk bersalin di rumah daripada ibu pendidikan tinggi, setelah dikontrol oleh variabel perancu.

\section{Saran}

1. Tenaga kesehatan perlu melakukan penyuluhan kepada ibu hamil secara lebih intensif untuk mencegah komplikasi persalinan pada ibu hamil risiko tinggi.

2. Perlu pemantauan pelaksanaan ANC yang memenuhi criteria $7 \mathrm{~T}$ dan anjuran persalinan petugas kesehatan untuk ibu risiko tinggi oleh petugas.

3. Meneliti pengaruh faktor penolong persalinan terhadap pemilihan tempat bersalin dengan mengendalikan faktor sosial ekonomi yang diukut berdasarkan pendapatan dan pengeluaran.

\section{Daftar Pustaka}

1. Depkes RI, (2002).Laporan Study Mortalitas 2001,Pola Penyakit Penyebab Kematian di Indonesia, Sekertariat Susenas Badan Penelitian dan Pengembangan Kesehatan ,Jakarta.

2. WHO, (1994). Safe motherhood care of mother and baby at the health centre: Apratical guide, maternal and safe motherhood programme division of family health, Geneva.

3. Depkes,(2005).Profil Kesehatan Indonesia 2003, Menuju Indonesia Sehat 2010, Jakarta

4. Depkes, 2003. Laporan Kajian pengadaan kegawatdaruratan obstetri dan neonatal di Kabupaten Serang,Setiarini Asih dkk, Depkes WHO,Jakarta.

5. Djaya Sarimawar,(1999).Penyebab Kematian Bayi Baru Lahir (Neonatal) dan Sistem Pelayanan Kesehatan yang Berkaitan di Indonesia Survei Kesehatan RumahTangga ,Puslitbang Ekologi Kesehatan,Badan Litbangkes.

6. Depkes, 2001. Rencana strategis nasional making pregnancy safer (MPS) di Indonesia 2001-2010, Jakarta.

7. Hatmadji,Harijati,dkk,(1999). Baseline Survey Safe Motherhood (SM) Project: Pendekatan Kemitraaan dan Keluarga diakses 18 April 2006 ; http:/www.ldfeui.org/Publications/RschAbstract/RA-Detailasp?q=004

8. Pratomo,Hadi,(2004).Bayi Lahir mati,diakses 4 Oktober 2005 ;http:/www.depkes.go.id/showclips.php?pid=464,Pratomo 
9. Monthe, Krisman. Tesis. 2001. Analisis terhadap pilihan tempat persalinan oleh ibu bersalin yang di tolong oleh tenaga kesehatan di wilayah kerja puskesmas teluk batang kabupaten ketapang propinsi kalimantan barat tahun 2000. Program pasca sarjana program studi ilmu keseha- tan masyarakat UI, Depok.

10. Notoatmodjo, Soekidjo. 2003. Pendidikan dan perilaku kesehatan. Rineka cipta: Jakarta. 